\title{
Inhalt
}

Fritz Peter Knapp

Mittelalterliche Erzählgattungen im Lichte scholastischer Poetik . .

Peter von Moos

Die Kunst der Antwort.

Exempla und dicta im lateinischen Mittelalter . . . . . . . . . . 23

Klaus Grubmüller

Fabel, Exempel, Allegorese.

Über Sinnbildungsverfahren und Verwendungszusammenhänge . . 58

Christoph Daxelmüller

Narratio, Illustratio, Argumentatio.

Exemplum und Bildungstechnik in der frühen Neuzeit . . . . . . 77

Richard Newhauser

Der 'Tractatus moralis de oculor des Petrus von Limoges und seine exempla . . . . . . . . . . . . . . . . . . . . . . . . 95

Nigel F. Palmer

Das 'Exempelwerk der englischen Bettelmönches: Ein Gegenstück zu den `Gesta Romanorumı? . . . . . . . . . . . . . . . . .

Brigitte Weiske

Die `Gesta Romanorum` und das `Solsequium` Hugos von Trimberg

Werner Williams-Krapp

Exempla im heilsgeschichtlichen Kontext.

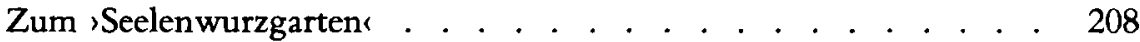

Volker Mertens

Das Verhältnis von Glosse und Exempel im Basler Plenar des Adam

Petri von 1514 


\section{Burghart Wachinger}

Der Dekalog als Ordnungsschema für Exempelsammlungen.

Der 'Große Seelentrostı, das 'Promptuarium exemplorum ‘ des Andreas

Hondorff und die ,Locorum communium collectanear des Johannes

Manlius . . . . . . . . . . . . . . . . . 239

Walter Haug

Exempelsammlungen im narrativen Rahmen: Vom $>$ Pañcatantrar zum

Dekameron. . . . . . . . . . . . . . . . . . . . . 264

Jacques Berlioz

Les recherches en France sur les exempla médiévaux, 1968-1988 . . 288 